University of Nebraska - Lincoln

DigitalCommons@University of Nebraska - Lincoln

Publications, Agencies and Staff of the U.S.

Department of Commerce

U.S. Department of Commerce

$10-2003$

\title{
A Novel Behavior Observed in Humpback Whales on Wintering Grounds at Abrolhos Bank (Brazil)
}

\author{
Maria Morete \\ University of Sao Paulo Sao Paulo \\ Ana Freitas \\ Marcia Engel \\ Richard M. Pace III \\ Phillip Clapham
}

Follow this and additional works at: https://digitalcommons.unl.edu/usdeptcommercepub

Part of the Environmental Sciences Commons

\footnotetext{
Morete, Maria; Freitas, Ana; Engel, Marcia; Pace, Richard M. III; and Clapham, Phillip, "A Novel Behavior Observed in Humpback Whales on Wintering Grounds at Abrolhos Bank (Brazil)" (2003). Publications, Agencies and Staff of the U.S. Department of Commerce. 162. https://digitalcommons.unl.edu/usdeptcommercepub/162

This Article is brought to you for free and open access by the U.S. Department of Commerce at DigitalCommons@University of Nebraska - Lincoln. It has been accepted for inclusion in Publications, Agencies and Staff of the U.S. Department of Commerce by an authorized administrator of DigitalCommons@University of Nebraska - Lincoln.
} 


\title{
A NOVEL BEHAVIOR OBSERVED IN HUMPBACK WHALES ON WINTERING GROUNDS AT ABROLHOS BANK (BRAZIL)
}

\author{
Maria E. Morete \\ Projeto Baleia Jubarte/Instituto Baleia Jubarte/IBAMA. \\ Praia do Kitongo $s / n^{\circ}$. Caravelas, BA, Brazil 45900-000 \\ and \\ Department of Ecology, Biology Instirute, University of São Paulo \\ São Paulo, SP, Brazil \\ E-mail:miamorete@terra.com.br \\ ANA Freitas \\ MARCIA H. ENGEI \\ Projeto Baleia Jubarte/Instituto Baleia Jubarte/IBAMA \\ Praia do Kitongo $\mathrm{s} / \mathrm{n}^{\circ}$. Caravelas, BA, Brazil 45900-000 \\ Richard M. Pace, III \\ Phillip J. Clapham \\ Northeast Fisheries Science Center, \\ 166 Water Street, Woods Hole, Massachusetts 02543, U.S.A.
}

\begin{abstract}
We describe a novel behavior, termed "tail-up," observed in humpback whales (Megaptera novaeangliae) on wintering grounds on Abrolhos Bank, Brazil. The behavior involves the whale positioned vertically in the water column with its tail in the air. With the exception of calves, tail-up was observed in all social classes, and its frequency increased through the end of the season. Tail-ups were recorded in $144(5.8 \%)$ of 2,465 groups of whales observed from a shore station, and in 297 (14.9\%) of 1,996 groups observed from vessel surveys; biases in each method suggest that the true frequency lies between these sources. One hundred and fiftytwo hours of continuous sampling showed that the duration of tail-up events lasted from a few seconds to $12 \mathrm{~min}$ and was longest in groups comprised of a single adult. The maximum duration of a recorded period that consistently included tail-up was $10 \mathrm{~h}$; however, some individuals were observed to engage in the behavior at night and for four consecutive days. Tail-up movement speed did not vary by social class; however, it varied according to wind direction and speed. The characteristics of tail-up that we observed showed that it differed from the descriptions of similar behaviors in other cetacean species. The function of tail-up is unknown, but we suggest that it may be a multifunctional behavior.
\end{abstract}

Key words: Megaptera novaeangliae, humpback whale, behavior, breeding ground, Abrolhos Bank, shore station, scan-counts, continuous sampling, theodolite tracking. 
The humpback whale's (Megaptera novaeangliae) migration is one of the longest of any mammal (Stone et al. 1990, Palsbøll et al. 1997), and has a major effect on many aspects of the biology and behavior of this mysticete (Clapham 2000). The adaptative significance of this migration remains unclear, and resolution of this question hinges upon clarification of the energetics of this species (Brodie 1975, 1977). In summer humpbacks are found from temperate to coastal zones, generally close to coastlines or in continental shelf waters (CeTAP 1982), where they feed and where little or no reproduction occurs (Chittleborough 1965, Dawbin 1966). During winter, when mating and calving take place, they are typically observed clustered around insular coasts or on offshore reef systems in the tropics (Dawbin 1966, Balcomb and Nichols 1982, Whitehead and Moore 1982).

Differences in behavior among distinct humpback populations are mainly related to feeding techniques (Weinrich et al. 1992, Hain et al. 1982, Jurasz and Jurasz 1979, D'Vincent et al. 1985). Although the behavior of humpback whales during the breeding season has been well studied (e.g., Tyack 1981, Glockner and Venus 1983, Baker and Herman 1984, Clapham et al. 1992), no one has noted the behavior described here. The "tail-up" behavior is observed among humpback whales on Abrolhos Bank, a winter breeding ground off the coast of Brazil (Siciliano 1997, Martins et al. 2001). This behavior involves whales positioned vertically in the water column with their tail and sometimes a portion of the caudal peduncle in the air. It is practiced from minutes to days, by both lone and associated whales. Having described this behavior to other researchers, we found others have observed humpbacks performing a similar behavior elsewhere (Madagascar and Comoros Archipelago-southeastern Africa, ${ }^{1}$ Colombia, ${ }^{2}$ along the east coast of Australia, ${ }^{3}$ and Hawaii ${ }^{4}$ ). Among other cetacean species, Payne (1980) described a behavior termed "sailing" in southern right whales (Eubalaena australis) off the Valdes Peninsula, Argentina. Right whales were also observed performing the sailing behavior off South Africa ${ }^{5}$ and in Abrolhos waters. Würsig and Clark (1993) described a "tailing" behavior in bowhead whales (Balaena mysticetus). Gray whales (Escbrichtius robustus) where observed "tailing" in calving lagoons of Baja California ${ }^{4}$ and it has also been seen in an odontocete species (Grampus griseus) in the Red Sea. ${ }^{6}$ Except for the sailing behavior observed by Payne (1980) which lasts for a few hours, all observations of this similar behavior were shorter in duration (seconds to a few minutes at a time) and were observed sporadically and at low frequencies when compared to our observations of tail-up behavior in humpback whales.

\footnotetext{
${ }^{1}$ Personal communication from Howard Hosenbaum, Wildlife Conservation Society, Bronx, NY 10460 , February 2003.

${ }^{2}$ Personal communication from Lilián Flórez-González, Fundación Yubarta, Carrera $24 \mathbf{F}$ oeste \#3110, Tejares de San Fernando, Cali, Colombia, October 2002.

3 Personal communication from Robert Paterson, P. O. Box 397, Indooroopilly, Queensland 4068, Australia, August 2000.

${ }^{4}$ Personal communication from Bernd Würsig, Department of Marine Biology, The Insticute of Marine Life Sciences, Texas A\&M University at Galveston, 4700 Ave. U, Bldg. 303, Galveston, TX 77551 , January 2001.

${ }^{5}$ Personal communication from Peter Best, Mammal Research Institute, University of Pretoria, Whale Unit, \% South African Museum, P. O. Box 61, Cape Town 8000, South Africa, August 2000.

${ }^{6}$ Personal communication from Libby Eyre, School of Biological Sciences, Macquarie University, NSW 2109, Australia, August 2000
} 


\section{METHODS}

Abrolhos Bank $\left(17^{\circ} 20^{\prime}-18^{\circ} 10^{\prime} \mathrm{S} ; 38^{\circ} 35^{\prime}-39^{\circ} 20^{\prime} \mathrm{W}\right)$ is located on an extension of the Brazilian continental shelf, off the southern coast of Bahia State. The Bank is characterized by water that is both warm (winter average temperature $=24^{\circ} \mathrm{C}$ ) and shallow (average depth $\sim 20 \mathrm{~m}$ ), as well as by an extensive coral reef system. These features are typically associated with breeding grounds for humpback whales in other locations (e.g., Whitehead 1981, Whitehead and Moore 1982, Clapham 1996).

\section{Field Observations}

Our observations were made during an ongoing long-term study of humpback whales on Abrolhos Bank. This study consisted of annual vessel surveys of the area, and shore-based counts from a station on Santa Barbara Island at Abrolhos Archipelago. From July to November observers spent approximately $80 \mathrm{~d}$ collecting photographs, biopsy samples, and underwater observations of humpbacks in the Abrolhos Bank area. Behavior, group composition, and geographic position were recorded. Individuals were photographically identified using variations in the ventral fluke pattern, as well as in the shape, size, and scarring of the dorsal fin (Katona and Whitehead 1981). Vessel observations were made from a 12.2-m wooden boat powered by a 6 -cylinder diesel inboard engine. The shore station was located $37.8 \mathrm{~m}$ above highest sea level, which permitted scan counts and continuous sampling behavioral observations (Mann 1999). Data from the shore station were collected during the entire field season using a Sokkia DT5 30-power digital theodolite and $7 \times 50$ binoculars. Each day's observations began with a one-hour scan at sunrise which recorded all humpback whales within a radius of $9 \mathrm{~km}$. Scans recorded data on group size and composition, location, and behavior and care was taken not to double count groups. After the initial one-hour scan, continuous sampling (Mann 1999) was used to collect behavioral data on a whale or an associated group of whales containing a maximum of two adults and one calf, as recommend by Altmann (1974) for reliable continuous data. To reduce measurement errors of the whale's position derived from theodolite tracking (see Würsig et al. 1991), the speed of the whale during tail-up events was calculated only for focal groups that were within a $4.5 \mathrm{-km}$ radius of the shore station. Sampling continued until the group either moved out of the study area, or until sighting conditions (rain, Beaufort State $>5$, or glare) reduced observation quality. During the 1998 and 1999 seasons, behavioral and theodolite data were recorded on a standard data sheet. In the following seasons, all data were entered in real time on a Macintosh Powerbook computer running a time-synchronized data-collection program, (Cornell "Aardvark," Mills 1996) designed for shore-based whale studies (e.g., Frankel et al. 1995, Frankel and Clark 1998). Data from the 1998 and 1999 seasons were also entered into Aardvark. Aardvark analyses were used to estimate whale speed and heading while exhibiting tail-up behavior. Every $30 \mathrm{~min}$ during continuous sampling, environmental conditions (wind speed, sea state, tide height, glare) were recorded.

\section{Definitions, Considerations, and Abbreviations}

We defined a tail-up event to mean the period during which the whale was engaged in tail-up delimited by periods at the surface to breathe, a bout as a series of 
events, resting as a state in which a whale remained motionless at the surface, active when a whale breached or performed tail and peduncle slashes, and traveling when a whale moved, alternating between periods at the surface and submerged. A whale was considered to be a female when a calf was present, or when it was possible to observed the genital area (Glockner 1983). In groups of mother, calf, and escort, the female was considered to be the animal in closer proximity to the calf. As all sexed escorts are male (Clapham 2000) and the fact that singers are always male (Glockner 1983, Baker and Herman 1984), the escorts and singers observed in this study were considered male. An adult is defined as a non-calf of unknown sex.

The movement of the whale while in tail-up was considered to be up wind when the wind was blowing $0^{\circ}-30^{\circ}$ in the opposite direction to the whale heading, down wind when the wind was blowing $140^{\circ}-180^{\circ}$ in the same direction as the whale heading, or crosswind (otherwise).

Group types considered in this study were: LONE, an adult whale alone; DYAD, a group of two adult whales; MOCA, a mother and calf group; MOCE a mother, calf, and one escort group; MOCE + , a mother, calf, and more than one escort group; TRIO, three adult whales together; and TRIO+, four or more whales together.

Social classes were a combination of sex (including unknown) and social group defined as follows: (1) male alone (MLONE), (2) unknown sex alone (ALONE), (3) the female in a mother and calf with escort (FMOCE), (4) the female in a mother and calf no escort (FMOCA), (5) an adult of unknown sex together with one other adult (ADYAD), (6) the escort animal in a mother and calf with escort (MMOCE), and (7) female, no calf, together with one other adult (FDYAD).

\section{Shore Base Scans Observation}

To describe the rate of occurrence of tail-up behavior among groups observed during one-hour scans in the area of $9 \mathrm{~km}$ around the shore station, we tallied the number of groups in which at least one tail-up behavior was observed $v$ s. all groups observed by month, by year, and group type. We examined these data in a logistic regression.

\section{Continuous Sampling Observations}

To describe patterns in the nature of tail-up behavior, we calculated summary statistics and performed mixed model analyses of continuous sampling data (Littell et al. 1996). In particular, we examined the relationship of tail-up event duration to social class and wind speed, while accounting for the fact that duration data represented repeated events by the same focal animal during an observation period. We treated all continuous sampling as independent because we had very incomplete knowledge of repeated sampling of individuals among continuous sampling. We elected to model duration of tail-up bouts in a two-step process. Treating each continuous sampling as a subject, we first found the best covariance structure to describe the repeated tail-up durations (selecting among auto-regressive, compound symmetry, and unstructured). We then selected the best set of fixed predictors among combinations of wind speed, social class, and their interaction (Littell $e t$ al. 1996). We selected among potential descriptive models by selecting the most parsimonious model with equivalent Akaike Information Criteria (AIC) values. Estimates are reported $\pm 1 \mathrm{SE}$. 

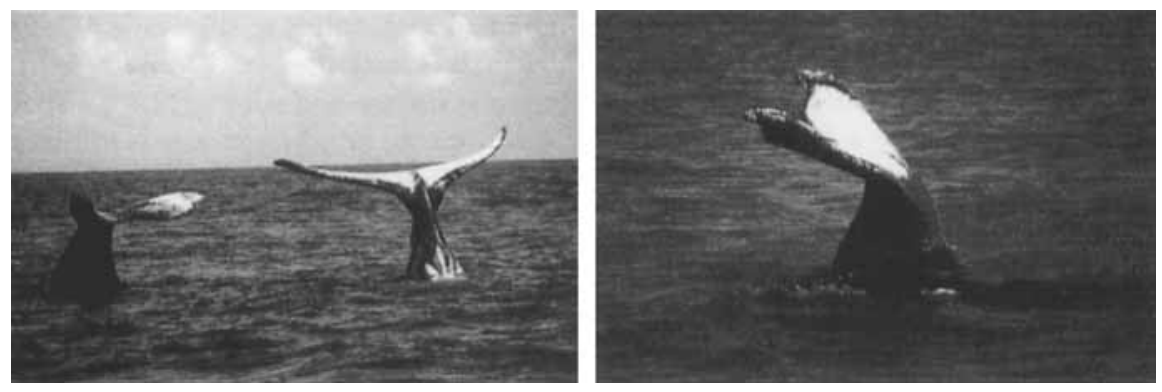

Figure 1. Two whales simultaneously and a mother engaged in tail-up behavior on Abrolhos Bank, Brazil.

For those continuous samples from which we were able to get travel direction relative to wind and speed during tail-up events, we tested the effects of social class, wind speed, and wind direction on animal speed in a mixed general linear model similar to the analysis of bout duration.

As a final description of tail-up behavior, we placed it in context with two orher principal behavioral states (traveling and resting). We calculated the percent time an animal was engaged in each of these behaviors for each focal follow. We tested for differences among social classes in the set of behaviors using a multivariate analysis of variance (MANOVA) and plotted the resulting means in a 3-dimensional behavior space.

\section{RESULTS}

\section{Tail-up General Aspects}

Tail-up behavior has been observed in the Abrolhos area since the beginning of the study in 1989. Humpback whales engaged in tail-up behavior positioned themselves vertically in the water column with the tail and sometimes a portion of the caudal peduncle in the air (Fig. 1). The tail itself was held straight up or was bent backwards with the plane of the flukes almost parallel to the water surface. Within a single bout, whales periodically suspended the behavior to breathe, but resumed the tail-up position afterwards. The length of time for which whales maintained the tail-up position in an event ranged from a few seconds to approximately $12 \mathrm{~min}$. The longest observed duration of a tail-up bout on any one day was $10 \mathrm{~h}$, which was the longest continuous sampling made in Abrolhos. Although we were unable to extend our observations into nighttime, tail-up behavior was observed being performed by a singer whale at night. ${ }^{7}$ In Abrolhos we observed four separate instances in which identified individuals conducted tailup behavior during at least four consecutive days.

In most cases, a whale engaged in tail-up behavior rotated slowly on its longitudinal axis. In almost all cases, whales prominently arched their caudal peduncles immediately prior to or after engaging in each tail-up, an act which may involve "stretching" muscles fatigued by prolonged periods in the tail-up position.

\footnotetext{
${ }^{7}$ Personal communication from Roberto Fortes, biologist, Coronado whale watching yacht charter, Praia do Grauça, Barra de Caravelas, Bahia, Brazil, October 2002.
} 
Table 1. Frequency of observations of tail-up, by group type, among humpback whales at Abrolhos Bank, Brazil.

\begin{tabular}{lccccc}
\hline \hline & \multicolumn{2}{c}{ Shore station } & & \multicolumn{2}{c}{ Vessel (1995-2000) } \\
\cline { 2 - 3 } \cline { 6 - 6 } Group type & Sightings & Tail-up & & Sightings & Tail-up \\
\hline LONE & 372 & 26 & & 466 & $76^{\mathrm{a}}$ \\
DYAD & 615 & 35 & & 522 & 82 \\
TRIO & 180 & 1 & & 137 & 14 \\
TRIO+ & 122 & 0,0 & & 143 & $14(9.8 \%)$ \\
MOCA & 692 & 51 & & 434 & 54 \\
MOCE & 418 & 29 & & 249 & 50 \\
MOCE+ & 66 & 2 & & 45 & $7(15,6 \%)$ \\
Total & 2,465 & 144 & & 1,996 & 297 \\
\hline
\end{tabular}

${ }^{a}$ At least $14(18.4 \%)$ of these 76 LONEs were confirmed to be singers.

Whales have been observed in the tail-up position in the whole Abrolhos Bank area and also outside the Bank in places up to $700 \mathrm{~m}$ deep. ${ }^{7}$

\section{Tail-up Frequency}

From vessel surveys in Abrolhos Bank we observed that tail-up was practiced among singletons, and in groups of all sizes and types, including a pregnant female. In the Abrolhos Bank area 983 individual whales have been identified photographically on vessel surveys from 1989 to 2000; of these, 111 (11.3\%) engaged in tail-up behavior $\geqslant 1$ times. Fifty $(5.1 \%)$ identified whales were observed in tail-up more than once. Twenty-eight whales exhibited tail-up whenever they were sighted (from 2 to 12 times). Some whales performed tail-up in various group types.

Of 66 MOCE+, 180 TRIO, and 122 TRIO+ groups observed during one-hour scans during 1998-2001, tail-up behavior was seen only three times (two in MOCE + and one in TRIO, Table 1). Because of the rarity of tail-up behavior among these groups in the $9 \mathrm{~km}$ around the archipelago, we did not consider them further in the analysis of seasonal patterns of the behavior. Logistic regression modeling provided no evidence $(P>0.1)$ that tail-up behavior frequency varied among the remaining group types considered (LONE, DYAD, MOCA, MOCE), or that tail-up was related to year $(P>0.5)$, but we found strong evidence that the frequency of the behavior varied among months, increasing gradually from $1.0 \pm 0.6 \%$ in July to $17.1 \pm 3.8 \%$ November (Fig. 2).

\section{General Description of Tail-up in Different Group Types}

While mothers exhibited tail-up, calves swam around them, diving close to the ventral portion of the mother's peduncle, which presumably represented attempts to nurse. Also, calves exhibited active behaviors, as tail slashes and breaches. In these cases, sometimes the mother suspended the tail-up bouts and also performed active behaviors. We observed a calf trying to hold its tail up only once, which may have been an effort to imitate the mother and an escort, which were both tailing-up at the time. In some cases, when lone whales where performing tail-up bouts, they 


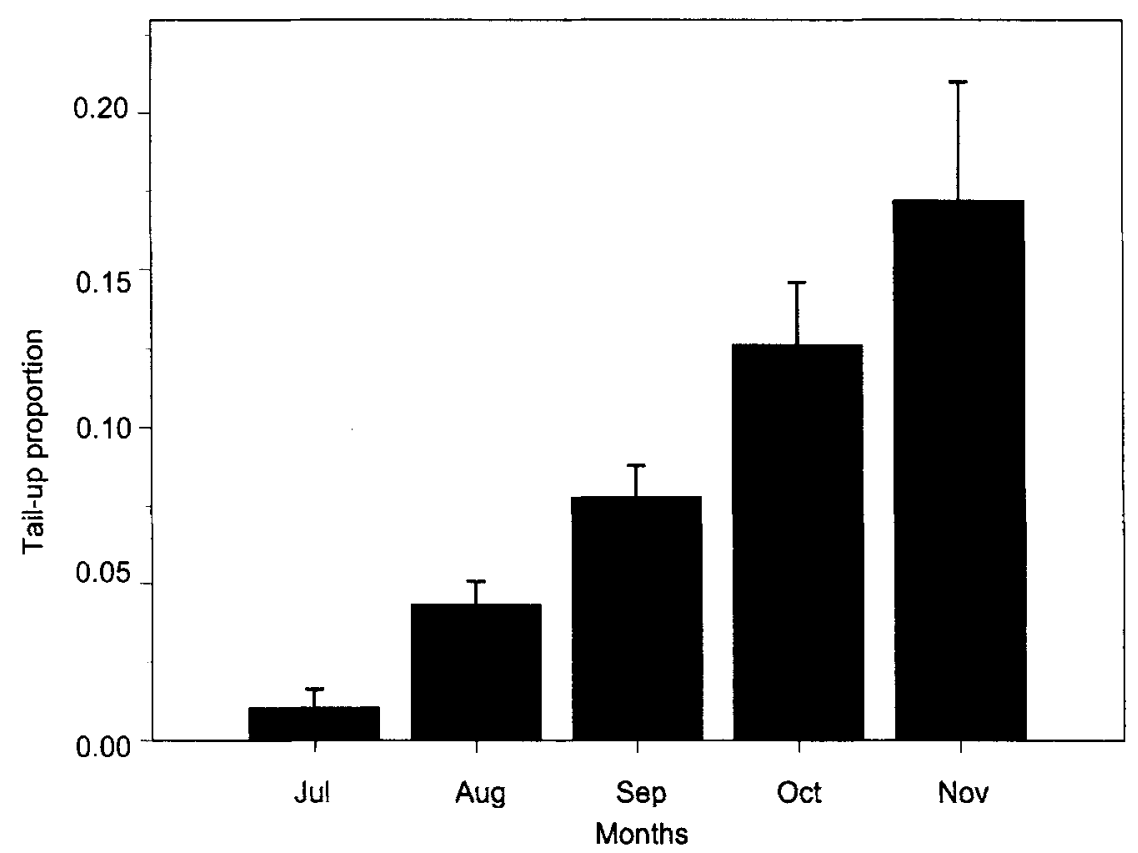

Figure 2. Proportion of humpback whale groups observed during one-hour scans (excluding MOCE+, TRIO, and TRIO+) from a shore based station in Abrolhos, Brazil, where at least one member perfomed tail-up behavior 1998-2001.

were joined by other adult whales for a brief period of time. Sometimes lone whales stopped exhibiting tail-up to join competitive groups. At other times, groups of whales would pass by just by the side of the whale that was tailing-up and no change in the whale behavior was noted. In DYADs or mother, calf, and one escort groups in which only one animal performed tail-up, the other whale spent most of the time submerged, surfacing to breath at the same time as the whale that was in tail-up. Whales usually traveled back to the area in which they started tailing-up after finishing the behavior. Although rare, tail-up also can be practiced by two adult whales simultaneously in groups of DYADs and mother, calf and escort groups. In these cases, one whale always initiated the behavior.

\section{Continuous Sampling of Tail-up Description}

One hundred and fifty-two hours of continuous sampling observations comprising 50 humpback groups were made. Based on AIC, the best model describing the 554 tail-up event durations used a compound symmetry covariance structure. There was strong evidence that duration varied by social class $(P<0.0001)$, and decreased an average of $6.1 \pm 2.2 \mathrm{sec}$ per $\mathrm{km} / \mathrm{h}$ of wind speed $(P=0.0064$, Fig. 3).

We analysed movement speed during 298 tail-up events for which 169 (56.7\%), $108(36.2 \%)$, and $21(7.1 \%)$ movement directions were downwind, crosswind, and upwind, respectively. We found no evidence that tail-up movement speed varied by social class. Based on AIC, the best model indicated that movement speed while 


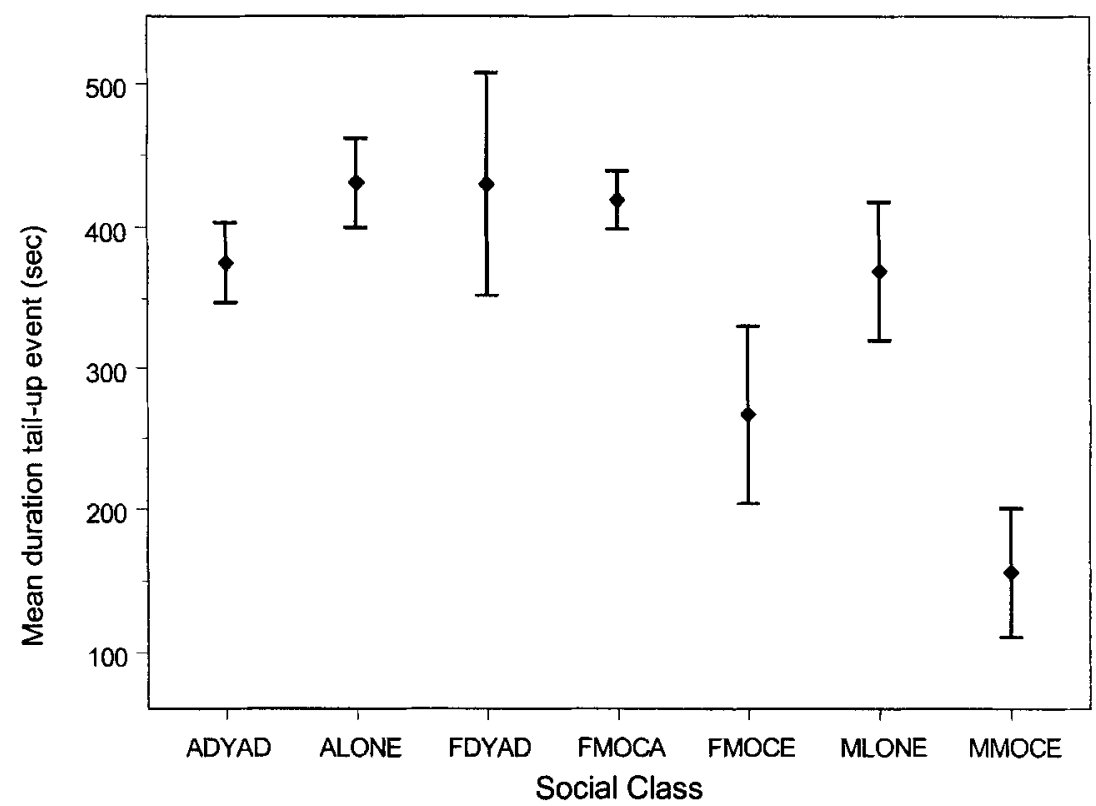

Figure 3. Mean duration (sec) of tail-up events for each social class: adult of unknown sex together with one other adult (ADYAD); unknown sex alone (ALONE); female, no calf, together with one other adult (FDYAD); the female in a mother and calf no escort (FMOCA); the female in a mother and calf with escort (FMOCE); male alone (MLONE) and the escort animal in a mother and calf with escort (MMOCE).

engaged in tail-up varied according to wind direction (down wind $>$ crosswind and upwind) and increased with wind speed. The closest competing model (AIC difference $=1.7$ ) also was consistent with the hypothesis that the tail-up acts as a sail (a regression model with the same intercept and different slopes for each wind direction with down wind $>$ crosswind and upwind). The analysis of durations of tail-up as a function of wind speed for each social class showed a tendency of similar durations among all social classes except for MOCE groups, which show shorter durations of tail-up events (Table 2).

All whales that performed tail-up alternated it with resting behavior during at least a part of the bout, and some interspersed tail-up/resting with periods of traveling, and short bouts of active behavior. The social classes distributed their time among behaviors differently (Wilk's Lambda $=0.5240$, df $=18,127$, $P=0.0291$ ), but in general whales not accompanied with other adult whales spent most of the time in tail-up followed by resting. Groups containing more than one adult spent more time either resting or traveling (Fig. 4).

\section{Discussion}

All cetaceans, including humpbacks, spend much of their time below the surface. Consequently, most behaviors occur out of sight. Understanding and demonstrating the function of behaviors is often difficult. This is especially true because each behavior might serve different functions depending on social context.

Tail-up behavior observed among humpback whales in the Abrolhos region does 
Table 2. $\quad P$ values of differences in estimated mean durations of tail-up events among different social classes, observed during continuous sampling of groups performing tail-up behavior in Abrolhos Archipelago area, Brazil, during the 1998-2002 humpback whale seasons. Cells with significant differences are bold and the difference (sec) between column and row social class is given in parentheses.

\begin{tabular}{lcccccc}
\hline \hline & ALONE & FDYAD & FMOCA & ADYAD & MLONE & FMOCE \\
\hline FDYAD & 0.993 & & & & & \\
FMOCA & 0.748 & 0.890 & & & & \\
ADYAD & 0.188 & 0.507 & 0.204 & & & \\
MLONE & 0.293 & 0.508 & 0.350 & 0.913 & & \\
FMOCE & 0.024 & 0.107 & $\mathbf{0 . 0 2 5 2}$ & 0.120 & 0.205 & \\
& $(103)$ & & $(152)$ & & & \\
MMOCE & $<0.0001$ & 0.0036 & $<0.0001$ & $\mathbf{0 . 0 0 0 1}$ & $\mathbf{0 . 0 0 2 4}$ & 0.158 \\
& $(275)$ & $(274)$ & $(263)$ & $(219)$ & $(213)$ & \\
\hline
\end{tabular}

not appear to have a single function, nor is it related to an animals' sex or social class. It was performed with considerable consistency by some identified whales, including both females and males, in different social contexts, and in different winter seasons. We suggest that it is a multifunctional behavior. Furthermore, its apparent absence from other studied populations of humpback whales provides strong evidence that it represents an example of cultural transmission.

Tail-up behavior is common among humpbacks in the Abrolhos Bank area, and it has been observed since the studies of these whales began in 1989. Tail-up is often performed for extended periods of time.

We have observed tail-up behavior from two different platforms; because these varied in sampling strategy, geographic coverage, and temporal coverage, they are not directly comparable. These two sources of information provide different measures of the frequency of tail-up behavior, and the actual day-time frequency probably lies somewhere between the two estimates. Observations of tail-up behavior among groups containing more than two adults (MOCE+, TRIO, and TRIO+) were rare in the scan data, but more common in vessel observations. Vessel observations were carried out in the entire Abrolhos region, not just the $9 \mathrm{~km}$ around the Abrolhos Archipelago. Our shore station scan data may underestimate the frequency of tail-up behavior, since once the size and type of a group is established during a scan, the observer moves on to the next group. Conversely, the vessel data likely overestimated the occurrence of this behavior, because whales engaged in tail-up were much more visible than others and were therefore more likely to be selected for further observation.

It is not clear why the frequency of tail-up behavior increases over the course of the season. This increase may indicate that, as more and more animals leave the breeding grounds, opportunities for courtship and mating activity decrease, allowing more time for the resting behavior with which tail-up seems to be associated.

We found that wind influenced tail-up behavior. The fastest movement of the whale while in tail-up coincided with higher wind speeds when the whale was heading downwind. In this manner tail-up could serve as a passive way of displacement or even could be an alternative position for resting; however, most of the observed whales would travel back to the area where they began the tail-up behavior, while some whales moved cross- and upwind while engaged in tail-up. 


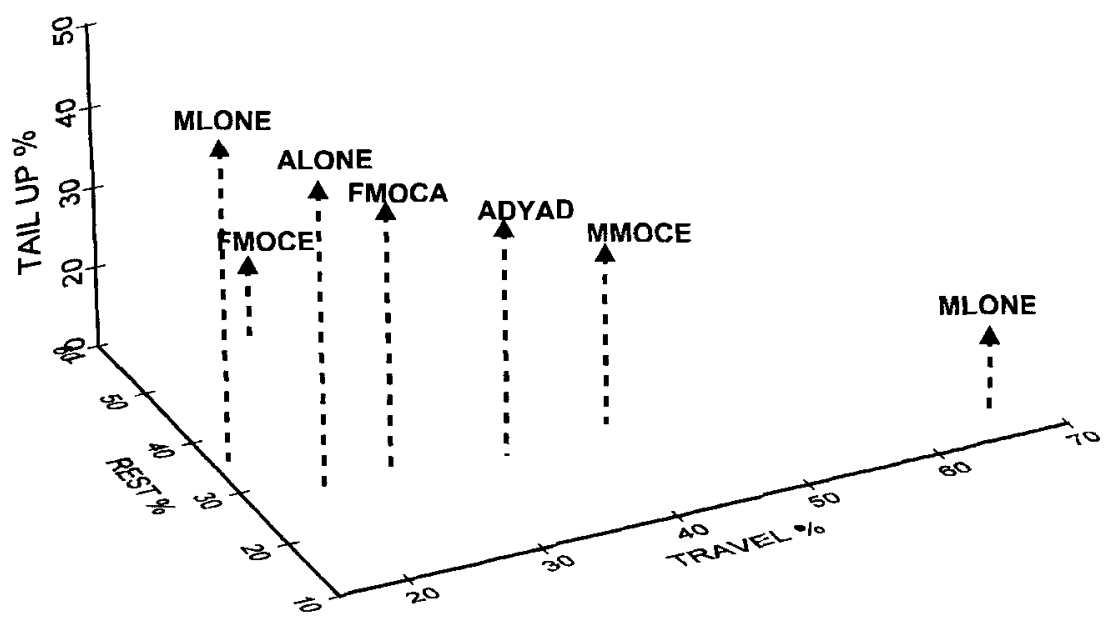

Figure 4. Mean time allocations (\%) among three principal behavioral states observed among humpback whales during continuous sampling from a shore-based station in Abrolhos, Brazil, during 1998-2001. Percent active was excluded because it was the least often recorded. Abbreviations: male alone (MLONE), unknown sex alone (ALONE), the female in a mother and calf with escort (FMOCE), the female in a mother and calf no escort (FMOCA), an adult of unknown sex together with one other adult (ADYAD), the escort animal in a mother and calf with escort (MMOCE), and female, no calf, together with one other adult (FDYAD).

Tail-up event duration was shorter when the wind was higher; this is explained presumably by the greater effort required to maintain the position in higher wind speeds. The rotation around the whale's longitudinal axis, plus the observed movement of the pectorals in underwater observations ${ }^{8}$ presumably reflects the whales' attempt to maintain this equilibrium.

Tail-up characteristics vary according to the social class of the individual performing the behavior. Whales not accompanied by another adult (lone or mother and calf group) had longer tail-up event durations and spent a larger proportion of their time tailing-up. Groups of two whales (DYADs) and the female and the escort in mother, calf, and one escort groups (MOCE) showed the highest percentages of traveling or resting and shorter durations of tail-up events. It seems likely that social interaction in such groups is more likely to interrupt tail-up.

Payne (1980) suggested that a southern right whale female would use the sailing posture in order to avoid mating. We have observed tail-up behavior among females in competitive groups and in mother, calf, and one escort groups. However, the fact that escorts and mothers sometimes tail-up simultaneously, that males also perform tail-up in competitive groups, and that tail-up occurs in other behavioral or social contexts (not associated with courtship), strongly suggests that avoidance of copulation is not the function of tail-up behavior.

Similarly, in one observation, we witnessed a calf suckling while the mother exhibited tail-up. However, it is clear that nursing is not the reason for the behavior,

\footnotetext{
8 Personal communication from Enrico Marcovaldi, underwater cinegraphist of Humpback Whale Project, Caixa Postal 2219, Salvador, BA, Brazil. CEP: 40.210-970, November, 2002.
} 
because nursing can be adequately performed in other positions; however, calves may attempt to nurse when their mothers are tailing-up, as mothers often spend long periods in this position.

Singers (MLONE) spent the highest percentage of time in tail-up during the observations. Sousa-Lima et al. (2002) observed that when the singer was tailing-up the amplitude of the recorded sounds increased significantly when compared to sounds recorded when the whale was traveling or resting. Sousa-Lima et al. (2002) suggested that the tail-up position may affect sound propagation by decreasing attenuation through the lowering of the animal's head and that the position enables the whale to produce louder sounds. The argument that they would expose the tail out of the water because the depth was not enough for the whale to be completely submerged seems implausible because humpbacks have been sighted tailing-up in places $700 \mathrm{~m}$ deep. ${ }^{7}$

As tail-up is used by different social classes in different contexts, we can speculate that it might have a common function for all the whales, related to thermoregulation. However, this inevitably takes us into the broader question of the energetics of humpback whales and other mysticetes, an issue which to date has proved difficult to study. Because data on key variables have been difficult to obtain, efforts to assess the energetics of humpbacks in either high or low latitudes have been inconclusive and sometimes contradictory. Brodie's (1977) contention that baleen whales migrate to warm waters in winter to conserve heat, and that their large size is therefore an adaptation for fat storage during the prolonged fasting which necessarily occurs at this time, is a popular idea but one which remains unproven. As the fluke tissues are highly vascularized we can speculate that the tailup position could be used to lose or conserve heat, and this would depend upon the combination of three factors: the position of the tail (upward or bent backwards), the envitonmental conditions (position of the sun, cloud coverage, wind speed, water and air temperature), and the pigmentation of the fluke (from all white to all black). Currently, there is no evidence to consider the thermoregulatory argument as anything more than speculation.

The frequency, the character and duration of tail-up bouts and events, clearly showed that this behavior differed from the similar behavior noted in other humpback populations, ${ }^{1,2,3,4}$ in others cetacean species ${ }^{4,5,6}$ and from Würsig and Clark's (1993) observations of the brief "tailing" behavior in bowhead whales. Tail-up behavior also differed in some respects from "sailing" in sourhern right whales at Peninsula Valdes, Argentina (Payne 1980). Tail-ups occurred in groups of all sizes and types, whereas in right whales sailing was observed primarily among single animals. The movement of humpback whales during tail-up behavior was not always downwind, as was the case with sailing. Sailing is observed for a short period (three or four hours) when compared with tail-up; sailing was suggested to be a form of play, but humpbacks involved in tail-up generally do not perform other behaviors except resting and travel. If play was involved we would expect calves to engage in tail-up, yet calves were the one class of whale that never performed this behavior (except for one trial observed).

Thus, the tail-up phenomenon appears to occur in Abrolhos waters with greater frequency than in others areas of the world, suggesting that it represents an example of a localized, culturally transmitted behavior. Regional or interoceanic differences in other humpback whale behaviors have been recorded, notably with regard to feeding. Significant differences in bubble-feeding techniques have been documented between the North Atlantic (Hain et al. 1982) and the North Pacific (Jurasz 
and Jurasz 1979, D'Vincent et al. 1985). Weinrich et al. (1992) documented the appearance and spread of what they termed "lobtail feeding" among humpback whales in the Gulf of Maine.

There is no evidence in our data for an increase in the frequency over the four years of observations in the area around the archipelago. This may be in part due to sampling issues, or it may indicate that currently there is no active transmission of the behavior within this population. Overall, tail-up remains an interesting, but asyet unexplained, phenomenon in this population. Whether this behavior is truly an example of cultural transmission is currently unclear, but merits further study both here and in other humpback whale habitats worldwide.

\section{ACKNOWLEDGMENTS}

Collection of data would not have been possible without the help of interns, especially Tatiana Bisi, Andressa Aoki, and the shore base team: Cristiane A. Martins and Claudia Petta. We also thank Abrolhos National Marine Park/IBAMA, the Brazilian Navy for logistic support in the archipelago, and Petrobras, the International Fund for Animal Welfare, and Arim Componentes para Fogões for funding part of the Abrolhos study. We give special thanks to Jim Darling, Bernd Würsig, and Don Bowen for their helpful reviews improving this manuscript. We also thank Marcelo Skaf and Henrique Illha, Abrolhos National Park's managers, and Maria Bernadete, Abrolhos Park ranger, for many kinds of help.

\section{Literature Cited}

Atrmann, J. 1974. Observational study of behavior and sampling methods. Behaviour 49:226-267.

Baker, C. S., ANd L. M. Herman. 1984. Aggressive behavior between humpback whales (Megaptera novaeangliae) in Hawaiian waters. Canadian Journal of Zoology 62:19221937.

Batcomb, K. C., and G. Nichols. 1982. Humpback whale censuses in the West Indies. Report of the International Whaling Commission 32:401-406.

Brodie, P. F. 1975. Cetacean energetics: An overview of intraspecific size variation. Ecology $56: 152-161$.

Brodie, P. F. 1977. Form, function and energetics of Cetacea: A discussion. Pages 45-58 in R. J. Harrison, ed. Functional anatomy of marine mammals. Volume 3. Academic Press, New York, NY.

CETAP. 1982. A characterization of marine mammals and turtles in the mid-and north Atlantic areas of the U.S. outercontinental shelf. Bureau of Land Management contract no. AA551-CTB-48. Cetaceans and Turtles Assessment Program, University of Rhode Island.

Chittieborough, R. G. 1965. Dynamics of two populations of the humpback whale, Megaptera novaeangliae (Borowski). Australian Journal of Marine and Freshwater Research 16:33-128.

Clapham, P. J. 1996. The social and reproductive biology of humpback whales: An ecological perspective. Mammal Review 26:27-49.

Clapham, P. J. 2000. The Humpback whale: Seasonal feeding and breeding in a baleen whale. Pages 173-196 in J. Mann, R. C. Connor, P. T. Tyack and W. Whitehead, eds. Cetaceans societies, field studies of dolphins and whales. University of Chicago Press, Chicago, IL.

Clapham, P. J., P. J. Palsbøli, D. K. Matilla, and O. Vásquez.. 1992. Composition and 
dynamics of humpback whale cc npetitive groups in the West Indies. Behaviour 122:182-194.

Dawbin, W. H. 1966. The seasonal mig atory cycle of humpback whales. Pages 145-170 in K. S. Norris, ed. Whales, dolph as and porpoises. University of California Press, Berkeley, CA.

D'Vincent, C. G., R. M. Nilson and 2. E. Hanna. 1985. Vocalization and coordinated feeding behavior of the humpback whale in southeastern Alaska. Scientific Reports of the Whales Research Institute, Tokyo 36:41-47.

Frankel, A. S., C. W. Clark, L. M. Herman and C. M. Gabriele. 1995. Spatial distribution, habitat utilization, and social interactions of humpback whales, Megaptera novaeangliae, off Hawaii, determined using acoustic and visual techniques. Canadian Journal of Zoology 73:1134-1146.

Frankel, A. S., AND C. W. CLARK. 1998. Results of low-frequency playback of M-sequence noise to humpback whale, Meyaptera novaeangliae, in Hawaii. Canadian Journal of Zoology 76:521-535.

Glockner, D. A. 1983. Determining the sex of humpback whales (Megaptera novaeangliae) in their natural environment. Pages $447-464$ in R. S. Payne, ed. Behavior and communication of whales. Westview Press, Boulder, CO.

GLOCKNER, D. A., AND S. C. VeNUS. 1983. Identification, growth rate, and behavior of humpback whale, Megaptera novaeangliae, cows and calves in the waters off Maui, Hawaii, 1977-79. Pages 223-258 in R. S. Payne, ed. Communication and behavior of whales. Westriew Press, Boulder, CO.

Hain, J. H. W., G. R. Carter, S. D. Kraus, C. A. Mayo and H. E. Winn. 1982. Feeding behavior of the humpback whale, Megaptera novaeangliae, in the western North Atlantic. Fishery Bulletin, U.S. 80:259-268.

JuRasz, C. M., AND V. P. JuRasz. 1979. Feeding modes of the humpback whale, Megaptera novaeangliae, in southeast Alaska. Scientific Reports of the Whales Research Institute, Tokyo 31:69-83.

Katona, S. K., AND H. P. WhiteheAd. 1981. Identifying humpback whales using their natural markings. Polar Record 20:439-444.

Littell, R. C., G. A. Milliken, W. W. Stroup and R. D. Wolfinger. 1996. SAS System for mixed models. SAS Institute Inc., Cary, NC.

ManN, J. 1999. Behavioral sampling methods for cetaceans: A review and critique. Marine Mammal Science 15:102-122.

Martins, C. C. A., M. E. Morete, M. H. Engel, A. C. Freitas, E. R. Secchi and P. G. KINAS. 2001. Aspects of habitat use patterns of humpback whales in the Abrolhos Bank, Brazil, breeding ground. Memoirs of the Queensland Museum 47(2):563-570.

MııLs, H. 1996. Aardvark. Cornell University, Ithaca, NY.

Palsbøll P. J., J. Allen, M. Berubé, P. J. Clapham, T. P. Feddersen, P. Hammond, H. Jorgensen, S. Katona, A. H. Larsen, J. Lien, D. K. Mattilla, J. Sigurjónsson, R. Sears, T. Smith, R. Sponer, P. Stevick and N. Oien. 1997. Genetic tagging of humpback whales. Nature 388:767-769.

PAYNE, R. 1980. Research on the behavior of various species of whales. National Geographic Society Research Reports 12:551-564.

SicILIANo, S. 1997. Características da população de Baleias-Jubarte (Megaptera novaeangliae) na costa brasileira, com especial referência aos Bancos dos Abrolhos. Masters thesis, Universidade Federal Rural do Rio de Janeiro. 113 pp. [In Portuguese]

Sousa-Lima, R. S., M. E. Morete, R. C. Fortes, A. C. Freitas and M. H. Engel. 2002. Impact of boats on the vocal behavior of humpback whales off Brazil. Journal of the Acoustical Society of America 112(5) pt. 2:2430.

Stone, G. S., L. Florez-GonzAlez ANd S. KatonA. 1990. Whale migration record. Nature 346:705.

TYACK, P. 1981. Interactions between singing Hawaiian humpback whales and conspecifics nearby. Behavior Ecology and Sociobiology 8:105-116. 
WeINRICH, M. 'T., M. R. Schilling AND C. R. BELT. 1992. Evidence for acquisition of a novel feeding behaviour: Lobtail feeding in humpback whales, Megaptera novaeangliae. Animal Behaviour 44:1059-1072.

WhiteheAd, H. 1981. The behavior and ecology of the humpback whale in the Northwest Atlantic. Ph.D. dissertation, Cambridge University.

Whitehead, H., AND M. J. MoORE. 1982. Distribution and movements of West Indian humpback whale in winter. Canadian Journal of Zoology 60:2203-2211.

Würsig, B., and C. W. Clark. 1993. Behavior. Pages 157-199 in J. J. Burns, J. J. Montague and C. J. Cowles, eds. The bowhead whale. Special Publication Number 2, The Society for Marine Mammalogy, Lawrence, KS.

Würsig, B., F. CiprIano AND M. Würsig. 1991. Dolphin movements patterns. Information from radio and theodolite tracking studies. Pages 79-111 in Karen Pryor and Kenneth Norris, eds. Dolphins societies, discovery and puzzles. University of California Press, Berkeley, CA.

Received: 20 September 2000

Accepted: 21 March 2003 